\title{
Blessed [Are] the Peacemakers... Grotius on the Just War and Christian Pacifism
}

\author{
Matthijs de Blois \\ Senior lecturer, Law Department, Institute of Legal Theory \\ Utrecht University \\ M.deBlois1@uu.nl
}

\begin{abstract}
In The Law of War and Peace Grotius needs many more pages for the theological arguments in the debate on war and peace than for the arguments derived from natural law and international law. Apparently the controversy within Christendom on the justifiability of warfare was one of the most important issues to be addressed in his magnum opus. The general discussion in his days was about the proper interpretation of the Holy Scriptures, the authority of which was accepted by all participants. This contribution focuses on the position of Hugo Grotius in this debate, confronting his ideas with the biblical arguments of those who (almost) completely rejected warfare, more in particular Erasmus and the Anabaptist branch of the Reformation. Grotius rejected the arguments in favour of Christian pacifism, which was to a considerable degree defended by Erasmus and which formed a central tenet of the Anabaptists. The latter's apolitical stand was not shared by Grotius or by Erasmus who were both albeit to different degrees involved in the political debate and practice in the field of war and peace.
\end{abstract}

\section{Keywords}

Grotius; just war; Christian pacifism; Erasmus; Anabaptists

\section{Introduction}

The interest in the work of the pre-modern Hugo Grotius ${ }^{1}$ remains undiminished also among the adherents to modernity. From many readings it seems to follow that he to a great extent fits the modern secular liberalism predominating legal philosophy. Recently Grotius was presented as the herald of modern

1 See B.P. Vermeulen and G.A. van der Wal, 'Grotius, Aquinas and Hobbes. Grotian natural law between lex aeterna and natural rights', Grotiana, 16/17 (1995/6), 58-78. 
Rawlsian liberalism. ${ }^{2}$ More established is the long tradition that qualifies Grotius as the seculariser of natural law, ${ }^{3}$ mostly based on the shaky ground of the well-known impious hypothesis, the most prominent quotation from Grotius in many introductory works on jurisprudence. The statement in the next paragraph of the Prolegomena, where he derives natural law from human nature as created by God, receives in many cases not the attention it deserves. The same is true of the reference to divine voluntary law referred to in that same paragraph. In many approaches the strong religious connotations of his work tend to be played down, in favour of a more fashionable secular reading of Grotius. As a result the explicit reliance in his work on the Bible as a source of not only moral but also legal principles is to a great extend ignored or at least seen as much less relevant than his purely philosophical natural law theory. It has also been interpreted as an ingenious device to secularise the law. ${ }^{4}$

The question is whether we do take the work of Grotius seriously, if we overlook the importance he himself attached to the proper use of the Bible in answering the important questions of law and morality. The fact is that in The Law of War and Peace Grotius needs many more pages to discuss the arguments derived from the Bible and from Church history than those from natural law and international law. Apparently the controversy within Christendom on the justifiability of warfare was one of the most important issues to be addressed in his magnum opus. The general discussion in his days was about the proper interpretation of Scripture, the authority of which was accepted by all participants. In this contribution I will focus on the position of Hugo Grotius in this debate, confronting his ideas with those of other writers who on biblical arguments completely or almost completely reject warfare. More in particular the positions of Erasmus and the Anabaptist branch of the Reformation will be discussed. To conclude I will compare the opinions of the biblically inspired peacemakers in the sixteenth and seventeenth centuries. We conclude with some final remarks.

\footnotetext{
2 Timothy Samuel Shah, 'Making the Christian World Safe for Liberalism', The Political Quarterly, 72 (2000), 121-139.

${ }^{3}$ See inter alia Knud Haakonssen, 'Grotius and the history of political thought' Political Theory, 13 (1985), 239-265, Jan \& Annie Romein, Erflaters van onze beschaving (Amsterdam: Querido, 1977), p. 252

${ }^{4}$ Mark Somos, 'Secularization in De iure praedae: from Bible Criticism to International Law', Grotiana 26-28 (2005-2007), 147-191.
} 


\section{Hugo Grotius}

Hugo Grotius is known as a man of peace. ${ }^{5}$ The impressive biography by Henk Nellen characterizes his life as a life in the service of peace. ${ }^{6}$ The motive to write The Law of War and Peace was to do something about the arbitrariness of war in the Christian world. Grotius observes that war is waged for trivial reasons or without any reason at all. At the closure of his treatise he appeals to his readers to pursue peace as the highest priority. ${ }^{7}$ Even if there is an example in his work of a bellicose attitude towards Spain, ${ }^{8}$ the general impression remains of the pursuit of peace as a predominant motive. The purpose of war is peace through law. This was already the theme of his The Law of Prize and Booty (De iure praedae) and was with even more strength stressed in his The Law of War and Peace. Grotius has been characterized as an irenicist," whose legal and theological publications are pervaded by a Christian humanism.

Hugo Grotius was, however, not a pacifist. He is in The Law of War and Peace, but also in other writings the man of the via media between the raison d'etat, which leaves no room for moral and legal limits of warfare, and Christian pacifism which referring to the commandment of charity rejects all warfare. Grotius has no affinity with the champions of the raison d'etat. He is however sympathetic of the pacifists, qualified by him as 'men, who are the furthest from being bad men'. ${ }^{10}$ May be that is the reason that he uses a plethora of arguments to refute their position.

The question whether it would ever be justified to wage war is answered by Grotius in The Law of War and Peace by using a threefold standard: natural law, human voluntary law and divine voluntary law. Grotius does not need many words to prove that natural law is not opposed to waging wars for selfpreservation. Also human voluntary law, more specific international law, does not prohibit warfare. The main focus in his argumentation is divine

5 W.J.M. van Eysinga, Gids voor De Groot's De Iure Belli ac Pacis [Guide for Grotius's De Iure Belli ac Pacis] Leiden: Brill, 1945, p. 7.

${ }^{6}$ Henk Nellen, Hugo de Groot. Een leven in strijd om de vrede 1583-1645 [Hugo Grotius, A life in contest for peace] (Amsterdam: Balans, 2007).

7 Hugo Grotius, De Jure Belli ac Pacis Libri Tres, vol 2. Translation. The Classics of International Law 3 (New York: Oceana, 1964), III.25. Hereafter LWP = The Law of War and Peace.

${ }^{8}$ C.G. Roelofsen, 'Grotius and the Development of International Relations Theory', Grotiana, 18 (1997), 97-120 at p. 113.

9 G.H.M. Posthumus Meyjes, Hugo Grotius as an irenicist, in: The World of Hugo Grotius (1583-1645) (Amsterdam \& Maarssen: APA, 1984), pp. 43-63.

${ }^{10}$ LWP, Prolegomena par. 29. 
voluntary law. Grotius the Christian, who abhors the abominations of war, feels the responsibility to justify himself to his coreligionists who with arguments derived from the Holy Writ reject all warfare. He takes a stand in a dispute on the moral acceptability of the use of violence which was going from the early days of Christianity. Already in Commentary on the Law of Prize and Booty he had discussed some biblical texts in this connection. The Law of War and Peace provides us with a more extensive, principled exposition.

Divine voluntary law does not contain anything that is contrary to natural law. It may, however, prohibit what is permitted by natural law. ${ }^{11}$ Therefore divine voluntary law as revealed in the Bible, should be examined. According to Grotius not all biblical commandments are binding for the whole of humanity. He distinguishes divine voluntary law binding for all peoples from the part that is written for one specific people, the people of Israel. This people received its Law at Mount Sinai, which by Moses was passed on to them. The whole of humanity (in so far as they could have known these commandments) is, to begin with, bound by the law that was revealed immediately after creation, secondly by the law that was given to Noah after the Flood and finally by the law of Christ in the New Testament. ${ }^{12}$ This subdivision provides us with the framework of Grotius's discussion of an impressive number of biblical texts, often applied to both the death penalty and warfare. In both cases the use of violence by the government is at stake. Who is in favour of the death penalty, justifies also warfare and the other way round. That follows from his discussion of the Noahide commandment in Genesis 9:5 and 6 :

And surely your blood of your lives will I require; at the hand of every beast will I require it, and at the hand of man; at the hand of every man's brother will I require the life of man. Whoso sheddeth man's blood, by man shall his blood be shed: for in the image of God made he man.

According to Grotius this text does not prohibit the shedding of blood as retribution, but only unlawful killing. ${ }^{13}$

The laws of Christ in the New Testament may according to our author impose obligations that go beyond what is required by natural law and the commandments in the Old Testament. ${ }^{14}$ They did not, however, abolish the power of government to apply violence. That is in the first place the

\footnotetext{
${ }^{11} L W P$, I.2. 5 and 6.

12 LWP I.1.15.2.

${ }^{13} L W P$, I.2.5. The Bible quotes here and below follow the King James Version.

${ }^{14} L W P$, I.2.6.
} 
consequence of the appeal to the Christian Church to pray for those in government, who if necessary have to ensure with the sword the peace of their subjects. ${ }^{15}$

A second proof is derived from the well known thirteenth chapter of St. Paul's Epistle to the Romans, where the government, who 'beareth not the sword in vain', is seen as ordained by God. ${ }^{16}$

Grotius attaches furthermore normative significance to what the Bible tells about the lives of a number of persons who participated in the army or the government. He shows that after their conversion to Christianity they were not forced to resign from their office or profession. He mentions in that connection the soldiers, baptized by John the Baptist, who were only instructed to refrain from extortion and false accusation and to be content with their wages. ${ }^{17}$ It is furthermore not told that the Roman centurion Cornelius left the army or was encouraged to do so after he became a Christian. ${ }^{18}$ There are no indications that the proconsul of Cyprus, Sergius Paulus, after his conversion resigned from office, nor that he was admonished to do so. ${ }^{19}$ That pious people sometimes do wage war can furthermore be derived from the book of Revelation (Apocalypse). In later editions this argument, however, is omitted. A number of arguments is also based on the biographical information on the Apostle Paul in the book of Acts, who did not refuse protection by an armed escort of soldiers, when he was threatened by an attack against his life. $\mathrm{He}$ furthermore said to the Roman procurator Porcius Festus that he would not resist the imposition of the death penalty if he deserved it.

The admonition of Paul to pay taxes is also an argument for Grotius that war can be justified; the proceeds will be used by the government to protect the good and punish the evil. ${ }^{20}$

Grotius argues not only from what has been written in the Scriptures, but also what has not been written. If Christ wanted to abolish the existing right to impose the death penalty, as well as armed protection against robbers and plunderers, He would have done so explicitly. According to Grotius, that cannot be inferred from the general or vague texts suggested in that connection. He refers also to the fact that Christ did not abolish the Mosaic criminal law, which prescribes the death penalty for murderers. ${ }^{21}$

${ }^{15}$ LWP , I.2.7.1 (1Timothy 2:1-4).

${ }^{16}$ LWP, I.2.7.3 and 4 (Romans 13:1-5)

${ }_{17}$ LWP I.2.7.5 (St. Luke 3:14)

${ }^{18} L W P$, I.2.7.9 (Acts 10)

19 LWP, I.2.7.10 (Acts 13:7-12)

${ }^{20}$ LWP, I.2.7.12 (Romans 13:6 and 7)

${ }^{21} L W P$, I.2.7.7 and 8 (St. Matthew 5:17) 
Grotius relates finally the right to punish and the use of arms against injustice to the general commandment in the New Testament to do what is honest and virtuous, which in his view refers to what according to the consensus among civilized peoples is considered to be in accordance with morality. ${ }^{22}$

The discussion of the biblical arguments in favour of the recognition of the right to wage war, is followed in Grotius's book by the rejection of the arguments derived from the Bible against this right. That brings him in a head-on confrontation with the theories of the Christian-pacifists.

First, Isaiah's prophecy on the peaceful Kingdom where 'they shall beat their swords into plowshares, and their spears into pruning hooks'. In Grotius's view this can be understood as a conditional prophecy, which will become reality when all men convert to Christianity and behave accordingly. It may also be interpreted as an unconditional prophecy, to be fulfilled in the future. In both interpretations it cannot serve as an argument against the justifiability of war. ${ }^{23}$

The core of the argumentation of the Christian pacifists is based on Jesus' Sermon on the Mount in the New Testament. Grotius's main effort is the refutation of these arguments. He uses his skills as a lawyer to interpret the texts referred to by his opponents in a restrictive way. An example is his interpretation of St. Matthew 5: 38 and 39:

You have heard that it was said, an eye for an eye, and a tooth for a tooth. But I say unto you, that ye resist not evil: but whosoever shall smite thee on thy right cheek, turn to him the other also.

According to Grotius the addressees of this text are not public officials, but people under attack. In addition it is clear that it concerns not all forms of injustice but only striking one's cheek. ${ }^{24}$ In the same way the texts that admonish the readers not to resist claims from their opponents are interpreted. ${ }^{25}$

On the texts of the Sermon on the Mount Grotius remarks in general that Christ demands more patience than the Old Testament law and that the answer to injustice should not always be retribution. However, this is not applicable to serious types of injustice. ${ }^{26}$

Grotius pays special attention to the commandment to love your enemy in the Sermon on the Mount. This does not exclude death penalty or war in his

\footnotetext{
${ }^{22}$ LWP, I.2.7.14 (Philippians 4:8; 1 Corinthians 11: 13-14).

${ }^{23} L W P$, I.2.8.1 (Isaiah 2:4)

${ }^{24} L W P$, I.2.8.3.

${ }^{25}$ LWP, I.2.8.4 (St. Matthew 5:40); I.2.8.5 (St. Matthew 5:41) and I.2.8.6 (St. Matthew 5:42).

${ }^{26}$ LWP , I.2.8.7 and 8.
} 
view, having regard to the commandment of neighbourly love in the Old Testament (understood by him as love for the members of your own people), which did not exclude the punishment of criminals. As a consequence the extension of the concept of neighbour and by that the commandment of charity to all men does not exclude the punishment of evildoers. Also God's love does not exclude His wrath. ${ }^{27}$

Next to the Sermon on the Mount Grotius discusses the Apostolic Epistles. The admonishment in Paul's Epistle to the Romans not to return evil for evil and to give place to God's wrath should not be understood as a prohibition to impose the death penalty or to wage a just war. It only excludes private revenge. ${ }^{28}$ Nor is the text in his Second Epistle to the Corinthians, that the weapons of our warfare are not carnal, but mighty through God, according to Grotius of any avail, since these words refer to a specific apostolic power over the church. ${ }^{29}$ The admonishment in the Letter to the church of Ephesus that they have not to wrestle against flesh and blood, refers to the spiritual warfare against devilish powers, and not to the struggle of people among each other. ${ }^{30}$

Furthermore, the passage in the Epistle of James where it is said that wars and fightings result from lust provides an explanation of war, but does not prohibit it in general terms. ${ }^{31}$

Finally Grotius reflects on the words spoken by Jesus to Peter, that those who take the sword shall perish by the sword. In his view this does not refer to war in general, but to a war between private persons. ${ }^{32}$

Grotius finds support for his view in the tradition of the early Church. The arguments against all use of force also derived from the earliest tradition of the Church are not convincing in his opinion, because they originate from some authors, like Tertullian, but do not represent the official position of the Church. ${ }^{33}$ Furthermore, he submits that the opposition to military service in the early days of Christianity was not so much rooted in a rejection of warfare as such, but related to special circumstances, such as the obligation to take an oath referring to Roman idols. ${ }^{34}$ Finally, he held that the pacifism of the early Christians was the expression of a life in accordance with the divine

\footnotetext{
${ }^{27}$ LWP, I.2.8.9-11 (St. Matthew 5:43,44).

${ }^{28}$ LWP, I.2.8.12-13 (Romans 12: 17-21).

${ }^{29}$ LWP, I.2.8.14 (2 Corinthians 10:4).

${ }^{30}$ LWP, I.2.8.15 (Ephesians 6:12).

${ }^{31} L W P$, I.2. 8.16 (James 4:1).

${ }^{32}$ LWP, I.2.8.17 (St. Matthew 26:52).

33 LWP I.2.9.2.

${ }^{34}$ LWP, I.2.9.3.
} 
admonishments for a life of a superior quality, without being a binding prescript. ${ }^{35}$

This approach is according to our author confirmed by church practice, which never refused baptism to soldiers, nor ever excommunicated them, and by Church Fathers and Councils. Only under special circumstances and in respect of Church officials did the early Church reject the military service. ${ }^{36}$

Summarizing we conclude that Grotius's views confirms the justifications of warfare that were developed within Christendom, certainly after Constantine, next to and in opposition of pacifistic views. His opinions are similar to those of John Calvin, who was to say the least, not Grotius's favourite. ${ }^{37}$ Grotius was nevertheless familiar with his Commentaries on the Bible and used them for his studies. Nellen tells us that during his imprisonment pending trial in 1619 Calvin's Commentary on a Harmony of the Evangelists Matthew, Mark and Luke was one of the books he consulted. ${ }^{38}$ In that Commentary Calvin observed in connection with the verses quoted above from Matthew 5 that judges and magistrates are entrusted with the defence of the community, and may therefore restrain the wicked, but that it is the duty of every [ordinary] man to bear patiently the injuries which he receives. ${ }^{39}$ As we have seen Grotius followed the same interpretation. His views on the just war are similar to those prevailing in the Republic the leading circles of which were strongly influenced by Calvinism. It is not surprising that a staunch Calvinistic, even puritan, theologian like Godfried Udemans, a contemporary of Grotius, quotes him with approval in a book published in 1638, which discusses the ethics of warfare from a theological perspective. ${ }^{40}$

\section{Erasmus}

In the Prolegomena of The Law of War and Peace Grotius clarifies his position towards those who with a reference to Christian charity reject all warfare.

35 LWP, I.2.9.4.

36 LWP, I.2.9.6-16.

37 See J. Bouterse, De boom en zijn vruchten. Bergrede en Bergrede-christendom bij Reformatoren, Anabaptisten en Spiritualisten in de zestiende eeuw [The tree and its fruits, Sermon on the Mount and Sermon-on-the-Mount Christianity of Reformers, Anabaptists and Spiritualists in the sixteenth century], Diss. Leiden (Kampen: Kok, 1986), pp. 256-278.

${ }_{38}$ Nellen, Hugo de Groot. Een leven, p. 236.

39 John Calvin, Commentary on a Harmony of the Evangelists Matthew, Mark and Luke, (translation William Pringle), Volume First (1845), reprint (Grand Rapids, MI: Baker Book House, 1979), p. 297.

40 Joris van Eijnatten, 'War, Piracy and Religion: Godfried Udemans's Spiritual Helm (1638)', Grotiana 26-28 (2005-2007), 192-214. 
He holds these pacifists in high regard, but thinks they have gone too far in their criticism of unjustified violence. ${ }^{41}$ For sure this high esteem concerns one of the writers mentioned explicitly in this connection, Grotius's compatriot Desiderius Erasmus ( \pm 1466-1536). This outstanding representative of Humanism was an exemplary ideal of scholarship for the intellectual elite of the Dutch Republic to which Grotius belonged. When the latter enters Leyden University at the age of eleven, he is welcomed with a poem by Dousa who compares the coming student to Erasmus. ${ }^{42}$ Grotius has some congeniality with this irenicist, to whom he in one of his early works refers as an ornament of his country, and someone who after the dark Middle Ages lit the light. $\mathrm{He}$ refers to him as the man who purified theology and praises him for his virtues. ${ }^{43}$ This appreciation remains. When Grotius in 1631 secretly returns to Rotterdam for a brief period, his first visit is to the then recently erected statue of Erasmus, who was said to be born there. ${ }^{44}$ Notwithstanding the fact that between the year of Erasmus's death (1536) and Grotius's birth (1583) there is a period of 47 years, it can safely be assumed that the ideas of Erasmus were still very much alive in Grotius's days, although many things had changed. During Erasmus's lifetime the professed unity of Christendom came under pressure by the emerging Reformation. In the days of Grotius the division between several Christian churches has become a fact of life. Sovereign Catholic and Protestant states coexist, albeit far from peaceful. Both Erasmus and Grotius were confronted with the cruel realities of war and both oppose its Machiavellian justification. Although Erasmus is more critical of warfare than Grotius, he is no more than his admirer a pacifist pure sang. That appears from the advice Erasmus gave at the request of the pope on the latter's plan to commence a war against Venice. There are in fact two advices. In the first he advises against waging such a war. In the second he indicates the circumstances under which such a war could be justified. This last advice was heeded by the pope. This second advice proves that under the circumstances Erasmus accepted warfare, notwithstanding the fact that it was it was clear that he preferred the first one. ${ }^{45}$

${ }^{41}$ LWP, Prol. 29.

${ }^{42}$ Nellen, Hugo de Groot. Een leven, p. 39.

43 In his Parallelon Republicarum, see Johannes Trapman, 'Grotius and Erasmus', in Hugo Grotius Theologian. Essays in Honour of G.H.M. Posthumus Meyjes, ed. by Henk J. Nellen and Edwin Rabbie (Leiden: Brill, 1994), pp. 77-98, at pp. 79-80 and also J. Trapman, Het land van Erasmus (Amsterdam: Balans, 1999), pp. 24-44, at p. 27.

${ }^{44}$ Nellen, Hugo de Groot. Een leven, pp. 366-367.

${ }^{4}$ See G.J. de Voogd, Erasmus en Grotius (Leiden: Nederlandsche Uitgeversmaatschappij, 1946), p. 61 and Trapman, Het land van Erasmus, pp. 43-44. 
That follows also from his most important writing on the legitimacy of warfare, 'Complaint of Peace', published in $1517 . .^{46}$ In this pamphlet against war Peace is introduced as a personified character, who complains that she is nowhere welcome in the world of human beings. It is completely different in the world of animals, plants and even not-living nature. Storks are examples of love in the family, the vine embraces the elm and a loadstone attracts iron and holds it fast in its embrace. ${ }^{47}$ But not only nature teaches us peace. Much more important for Christians is the teaching of Christ, which should lead to peace. Peace has to observe that that is an illusion:

(...) when I also hear the title of Christian added to the name of Man, I fly with additional speed, hoping that with Christians I may build an adamantine throne, and establish an everlasting empire. But here also, with shame and sorrow, I am compelled to declare the result. Among Christians, the courts of justice, the palaces of princes, the senate-houses and the churches, resound with the voice of strife, more loudly than was ever heard among nations who knew not Christ. ${ }^{48}$

The situation among Christians is therefore a sad one. Erasmus confronts them with the mirror of the Holy Writ and points at the announcement of Christ by the prophet Isaiah as the Prince of Peace and the prophecy of the Kingdom of Peace by the same. He furthermore mentions the apostle Paul, who preferred charity to all the other gifts of the Spirit of God and who referred to Christ as the God of Peace and Peace of God. The reference to God in the Bible as the God of hosts and the God of vengeance is not an argument for warfare. These expressions should be interpreted allegorically according to Erasmus. He also remarks that there is a big difference between the God of the Jews and the God of the Christians, although God in His essence is one and the same. This rather obscure passage does not prevent Erasmus to derive arguments from the Old Testament in order to defend his message of peace. Isaiah has been mentioned already. He further refers to the fact that not the warrior David, but his son Solomon, the Prince of Peace, was permitted to build the temple.

\footnotetext{
46 See for an English translation the Online Library of Liberty: http://oll.libertyfund.org/ index.php?option=com_staticxt\&staticfile=show.php\%3Ftitle... It is also included in John P. Dolan, The Essential Erasmus (New York: New American Library, 1964), pp. 177-204 (more a paraphrase).

47 Dolan, The Essential Erasmus, p. 178.

${ }^{48}$ Quotation from the English translation in the Online Library of Liberty: http://oll.libertyfund.org/index.php?option=com_staticxt\&staticfile=show.php\%3Ftitle... p. 7. See also Dolan, The Essential Erasmus, p. 180
} 
This Solomon was in Erasmus's eyes the type of Christ, the Son of God, Who came to reconcile the world with His Father. When Christ was born angels sang of peace. He addressed his followers with words of peace and instructed them to love one another and to live in peace even with enemies and strangers. Erasmus concludes that in all of Scripture, in both the Old and the New Testament, peace and concord are dominant themes. ${ }^{49} \mathrm{He}$ is appalled by the fact that Christians were waging war against each other, strongly supported by the clergy. Erasmus abhorred of the performance of pope Julius II (1503-1513), whose entry as military commander in Bologna on November $11^{\text {th }}, 1506$ he witnessed..$^{50}$ Peace wonders how it is possible to preach Christ and at the same time praise war. How is it possible to pray the Lord's Prayer while slaughtering your fellow Christians? Praying: 'forgive us our debts, as we forgive our debtors', while murdering your brother makes no sense. ${ }^{51}$ The unity in Christ should be much more important than the differences in nationality, which too often lead to enmity.

Notwithstanding what has been said so far Erasmus is aware that sometimes war (between Christians) cannot be avoided. It is then important to conduct the war in such a way that the calamities fall upon those who gave the occasion and not on the farmers and the ordinary people..$^{22} \mathrm{He}$ also provides for recommendations how to prevent war as much as possible. Kings should betroth their children to somebody within their own realms or otherwise exclude them from succession, in order to prevent dynastic conflicts. Borders have to be determined by lasting covenants. The only interest of kings should be the well-being of the public. They should not make long trips nor transgress the borders of their kingdom. ${ }^{53}$ When it comes to the question of waging war they better consult old men of integrity and war should only be entered into with the consent of the people. Sometimes war can be avoided by 'buying' peace. Erasmus urges the clergy not to countenance war and to refuse to bury those slain in the battle in consecrated ground..$^{54}$

Erasmus's judgment on wars in protecting Christians against invading barbarians is different. He admits that it is to be preferred to persuade Turks to adopt the Christian religion by friendly treatment, teaching and the example

\footnotetext{
49 See for the references to the Bible Dolan, The Essential Erasmus, pp. 182-186.

${ }^{5}$ J. Huizinga, Erasmus, (Rotterdam: Donker, 1978), p. 80. See also Dolan, The Essential Erasmus, pp. 190-191.

51 Dolan, The Essential Erasmus, p. 191. The quotation is from St. Matthew 6:12.

52 Dolan, The Essential Erasmus, p. 194.

53 Dolan, The Essential Erasmus, pp. 194-195.

${ }_{54}$ Dolan, The Essential Erasmus, p. 195.
} 
of an innocent life. If that is however not successful, then the objections against an inevitable warfare are not as strong as in the case of war within Christendom..$^{5}$

To conclude, Peace urges the reader to examine his own intentions. He points at the corruption of our earthly existence. Princes, priests, theologians, magistrates and all Christians are admonished to listen to the voice of Christ the King.

Huizinga observed that ideas of Erasmus influenced William of Orange and especially the leading urban magistrates in the Dutch Republic. According to this historian this appears from the fact that the history of the Netherlands is less sanguinary and cruel as compared to neighbouring countries. ${ }^{56}$ The question is whether this should be seen as exclusively the fruit of the moderate pacifism of Erasmus. In what follows it is suggested that we can point at another source.

\section{The Anabaptists}

According to the historian Fruin, the 'rediscoverer' of Grotius's Commentary on the Law of Prize and Booty, the latter was also confronted with a Christian pacifism of a more radical nature when he as a young lawyer in 1604 was asked by the VOC (The United East India Company) to justify afterwards the seizure of the Portuguese carrack, the Santa Catarina, by an Amsterdam fleet under the command of Jacob van Heemskerck. The occasion was supposed to be the conscientious objections of inter alia Anabaptist stockholders against warfare and robbery. We are told by Fruin that some of them gave their share in the spoils to the poor and that others sold their shares and by that left the VOC. He wonders why in the literature of those days there are no traces of these objections. ${ }^{57}$ In my view this is not that strange, having regard to the fact that for the Anabaptists of the seventeenth century separation from this world in general and from political life in particular was an important tenet of faith. A public discussion on the legitimacy of warfare or the right to capture does

55 See Erasmus, On the War against the Turks (De bello turcico), in: Erika Rummel (ed.) The Erasmus reader (Toronto: University of Toronto Press, 1990), pp. 315-333 and Dolan, The Essential Erasmus, p. 196.

${ }^{56}$ Huizinga, Erasmus, p. 217.

57 R. Fruin, Een onuitgegeven werk van Hugo de Groot [An unpublished work of Hugo Grotius], in Robert Fruin's Verspreide geschriften, vol. 3, ed. by P.J. Blok, P.L. Muller en S. Muller (The Hague: Nijhoff, 1901), pp. 367-443, at p. 399. 
not fit such an approach; withdrawal from the VOC in case of conscientious objections does. A number of Anabaptists established under the protection of King Henry IV, a peaceful counterpart of the VOC in France, eventually without success. In a briefing from the French ambassador at The Hague the initiator Pieter Lijntgens is described as a

fort Anabaptiste' [who] 'improuve toute sorte de port d'armes, soit offensives soit défensives, et principalement les combats et prises qui se sont faites par les flottes de ce pays sur les Portuguais. ${ }^{58}$

It should be added that Van Ittersum recently raised strong objections to Fruin's thesis. ${ }^{59}$ She refers to the fact that Pieter Lijntgens or the Mennonites or Anabaptists as such were never mentioned by Grotius. Moreover, she is convinced that Lijntgens 'was a rather unscrupulous character, whose alleged Mennonite sympathies did not preclude a serious involvement in arms trade. ${ }^{60}$ All this does not exclude, however, that the reasoning in Grotius's Commentary on the Law of Prize and Booty should be understood against the background of the pacifist ideas of the Mennonites, whatever the other interests at stake in the Santa Catarina case. It may on the other hand of course, lead us to doubts as to the moral integrity of Lijntgens. History, unfortunately, gives us many examples of people who do not always practice what they preach.

In his Commentary on the Law of Prize and Booty Grotius opposes pacifist views vehemently and with certain indignation. He does indeed not mention the Mennonites or Anabaptists explicitely but it is in my view rather obvious, having regard to the religious climate in the Dutch Republic in the early seventeenth century that he has these pacifist Protestants in mind. He compares them - not very friendly - with the heretic Manicheans ${ }^{61}$, opposed by Augustine, and he uses terms like 'superstition' and 'fanatics'. ${ }^{62}$ Grotius's purpose is not so much to disprove their opinions as well as to strengthen their opponents with a number of arguments mainly derived from the Bible. The Anabaptists had not many adherents in the leading circles in which Grotius participated. They were in general the 'quiet in the land'63, who purposively

\footnotetext{
58 Quoted by Fruin in footnote 2 in Fruin, Een onuitgegeven werk, p. 402.

59 Martine Julia van Ittersum, Profit and Principle. Hugo Grotius, Natural Riights Theories and the Rise of Dutch Power in the East Indies (1595-1615) (Leiden: Brill, 2006), pp. 114-122.

${ }^{60}$ Van Ittersum, Profit and Principle, p. 120.

${ }^{61}$ Manicheism mixes elements of the old dualistic Persian religion with Christianity.

${ }^{62}$ Hugo Grotius, Commentary on the Law of Prize and Booty, Commentary on the Law of Prize and Booty, Edited and with an Introduction by Martine Julia van Ittersum, (Indianapolis: Liberty Fund, 2006), p. 51.

${ }^{63}$ Psalm 35:20.
} 
refrained from politics and primarily devoted themselves to trade, industry and farming. Later on in his life Grotius comes again across Anabaptist ideas on the legitimacy of warfare. In 1641 he receives a letter of an acquaintance, Nicolaas de Bye, who addresses Grotius as 'waerde neeff (dear cousin). ${ }^{64}$ This Nicolaas de Bye tries to refute Grotius's thesis in The Law of War and Peace, that under conditions Christians are allowed to wage war, with numerous biblical arguments. In a letter to his brother Willem, Grotius presumes that De Bye is a Mennonite (by which name Anabaptists were known in the Netherlands). ${ }^{65}$ The arguments used by him in any case fit the Anabaptist theology. From his letter to Willem it can be derived that Grotius has become gentler towards the adherents of Anabaptist pacifism as compared to his indignation in his Commentary on the Law of Prize and Booty.

Time has come to explore more in depth the backgrounds of this pacifism.

The Anabaptist movement can be seen as the most radical branch of the Reformation, which developed next to and gradually also in opposition to Lutheranism and Calvinism.

Its cradle can be found in Switzerland at the beginning of the sixteenth century. It spread over Europe and via Emden it also reached the Low Countries, where it found many followers. Around 1630 they amounted to $10 \%$ of the population of the Dutch Republic. ${ }^{66}$ The Anabaptist movement refers to a great variety of theological opinions. Some common tenets make it possible to characterise this movement, however, as opposed to both Catholicism and other Protestant denominations.

The first point is that Anabaptists stress that the coming of Christ meant a new phase in God's history with mankind. As a consequence not everything that was permitted or commanded under the Old Testament dispensation was applicable to a member of the Christian church. ${ }^{67}$ The majority of the Anabaptists thought that as a consequence participation in the government or the use of the sword could not be defended with arguments derived from the Old Testament. For followers of Christ the use of the worldly sword

${ }^{64}$ Briefwisseling van Hugo Grotius, vol. 12, [Correspondence of Hugo Grotius], ed. by Paula Witkam (The Hague: Martinus Nijhoff, 1986), pp. 224-242. Hereafter: $B W 12$.

${ }_{65} B W 12$, pp. 269-270. The editor of this volume of his correspondence did not find indications for this.

${ }^{66}$ S. Groenveld, J.P. Jacobszoon en S.L. Verheus, Wederdopers, menisten en doopsgezinden in Nederland 1530-1980 (Zutphen: Walburg Pers, 1993), p. 198.

${ }^{67}$ O.H. de Vries, Leer en praxis van de vroege dopers uitgelegd als een theologie van de geschiedenis [Doctrine and praxis of the early Anabaptists interpreted as a theology of history] Diss. Utrecht, (Leeuwarden: Dykstra, 1982), passim, and Roland H. Bainton, Christian Attitudes Toward War and Peace, (Nashville: Abingdon, 1982), pp. 153-161. 
is excluded. In an early Anabaptist pamphlet we read that they acted like the early Christians from the time of the apostles till Constantine, who did not participate in government nor used the sword. ${ }^{68}$ It is furthermore important to stress the Anabaptist view of the church. This is seen as a visible community of true believers, who entered therein voluntarily and were baptised after a personal confession of faith. This is difficult to reconcile with the idea of an established church or a people's church. The government should not interfere in the affairs of the church, while the latter should not avail itself of political power for its purposes. The Frisian Anabaptist reformer Menno Simons held already in 1554, referring to the Bible, that political power should not be used to protect the true faith: '... Christ Jesus with His strong Word and Holy Ghost is the Saviour and Protector of His Church or Realm, and not the Emperor, King or whatever worldly power in eternity.' ${ }^{69}$ The stress is on the separation between Church and State, and also between the church of the elect and society as such. Being in the world but not 'of the world'70 is taken very seriously. Anabaptists also understand the commandment in the Sermon on the Mount, not to swear at all, ${ }^{71}$ in a literal sense and refuse to take an oath. With a direct reference to texts in the New Testament they further reject participation in the use of violence by the government, both in the field of justice and in the military. In one of the oldest documents of Anabaptist doctrine, drafted by Swiss Anabaptists in 1527, the Brüderliche Vereinigung or the Schleitheim Confession of Faith, we find these tenets exemplified. From Article 4 on the separation of the Church from this world we quote the following:

Thereby shall also fall away from us the diabolical weapons of violence - such as sword, armor, and the like, and all of their use to protect friends or against enemies - by virtue of the word of Christ: 'you shall not resist evil.'

And in Article 6, on the use of the sword, we read:

We have been united as follows concerning the sword. The sword is an ordering of God outside the perfection of Christ. It punishes and kills the wicked and guards and protects the good. In the law the sword is established over the wicked for punishment and for death and the secular rulers are established to wield the same. But within the perfection of Christ only the ban is used for the admonition

\footnotetext{
${ }^{68}$ Hans J. Hillerbrand, 'An Early Anabaptist Treatise on the Christian and the State', Mennonite Quarterly Review, 32 (1958), pp. 28-47

${ }^{69}$ In H.W. Meihuizen, Menno Simons, Haarlem 1961, p. 120.

70 St. John 17: 15-18

${ }^{71}$ St Matthew 5: 34.
} 
and exclusion of the one who has sinned, without the death of the flesh, simply the warning and the command to sin no more. ${ }^{72}$

The separation between the church and the world entails different roles. For a Christian living in the perfection of Christ the use of the sword is excluded in all circumstances. Inside the church only the ban may be used. In society as such the position is different. The legitimacy of the use of violence by the worldly government as an order outside the perfection of Christ is recognized. It is a 'Two Kingdoms' doctrine in its most radical form. ${ }^{73} \mathrm{~A}$ few decades later we find in Anabaptist circles in the Low Countries ideas similar to those of the Swiss brethren. Their leader was the already mentioned Menno Simons (14961559), the former priest of the village of Witmarsum in Frisia. Anabaptists are therefore both in and outside the Netherlands also known as Mennonites. Menno Simons taught his followers obedience to the government as a divine institution. For a Christian the use of the sword is however excluded. Menno's followers are allowed to battle only with the 'spiritual sword', that is the Bible. They have to submit to oppression and persecution and endure this in patience. Menno Simons strongly condemned the Anabaptists who with violence tried to establish the kingdom of God on earth in Münster, an experiment which was brought to an end by force in $1535 .^{74}$

The Anabaptist defenselessness is an Article of faith in the so called Dordrecht Confession of Faith which was adopted on April 21 $1^{\text {st }}, 1632$ by 51 Frisian and Flemish preachers. ${ }^{75}$ After recognition of the government as ordained by God to punish the evil and protect the good, follows the rule for Christians: not to oppose an enemy with the sword and not render evil for evil, but rather turn the other cheek. Following Jesus' example they should suffer without resistance and rather flee. Their duty is to pray for their enemies, and seek their well-being, everything in obedience to Christ. That non-resistance and enemy-love was not only preached but also practised is illustrated by a story told by Huizinga on a certain Dirk Willemsz. van Asperen, an Anabaptist believer, who rescued his persecutor from being drowned under the ice. He was nevertheless arrested and burned at the stake. ${ }^{76}$

\footnotetext{
72 Translation by John Howard Yoder in: The Legacy of Michael Sattler, Herald Press, 1973. See also members.iquest.net/ -jswartz/schleitheim/-

73 J. Bouterse, De boom en zijn vruchten, p. 128.

${ }^{74}$ Meihuizen, Menno Simons, pp. 141-150 and 221-222; M.C. Postema, Het spoor van Menno Simonsz' gedachten, [The track of Menno Simonsz' thoughts] (Kampen: Kok, 1986), pp. 54-59.

75 The Mennonite Encyclopedia, vol. 2, Scottdale, PA: Mennonite Publishing House, 1956), pp. 92-93.

${ }^{76}$ J.H. Huizinga, Nederlands beschaving in de 17 e eeuw [Dutch civilization in the seventeenth century] (Groningen: Noordhoff, 1984), pp. 65-66.
} 
The Anabaptist vision on warfare is elaborated in the letter referred to above, which Grotius received from De Bye. He submits that the right to wage war has expired after the coming of Christ. In an extensive reasoning he refutes Grotius's twelve arguments in The Law of War and Peace which purport to show that the right to wage war has not been abolished completely at the coming of Christ. It is relevant to mention a few examples from De Bye's letter. He refers for example to the argument used by Grotius derived from the admonishment of the apostle Paul to pray for those in power. De Bye comments that this does not imply that these rulers were Christians or that kings converted to Christianity remained kings. ${ }^{77}$ Moreover, the commandment to pray for the government does not mean that it acts in accordance with God's will. ${ }^{78}$ De Bye strongly underlines that behaviour in the community of Christians should differ radically from that in the world. ${ }^{79} \mathrm{He}$ is not impressed by examples in the Bible of government officials who converted to Christianity. It is indeed not stated that they quitted their position in the army or as a proconsul, but at the same time it is not indicated that they did not quit. Therefore these instances cannot be used. ${ }^{80}$ It is remarkable that De Bye sometimes fights Grotius with his own arms, if this metaphor is appropriate in this connection. De Bye refers to some passages in The Law of War and Peace and other writings that show a certain affinity of Grotius with Anabaptist ideas. An example is a place in Chapter 22 of Book II, where Grotius discusses the right of the apostles to judge members of the Church. According to Grotius that judgment should not be applied by means of sword or rod, but with the Word of God. Grotius adds in this connection the word of Christ that His kingdom is not of this world. ${ }^{81}$ De Bye further refers to the fact that Grotius discourages a true Christian to accept a public office which obliges him to judge on life or death, as if he were God. Has not Christ warned us not to judge others, for with the measure we mete we shall be measured. ${ }^{82}$ Grotius has also referred himself to Matthew 6: 14 and 15 to underline that we are obliged to forgive those who have trespassed against us. ${ }^{83}$ De Bye addresses also elaborately the arguments brought forward by his 'cousin' not to enter into war too rapidly, even if the war as such is legitimate. The exhortations

$77 B W 12$, p. 226.

${ }_{78} B W 12$, p. 228.

$79 B W 12$, p. 229.

${ }^{80} B W 12$, pp. 234 and 236.

${ }^{81}$ LWP, II.22.14.1 and 2.

${ }^{82}$ LWP, II.20.16. The reference is to St. Matthew 7:1 and 2.

${ }^{83}$ LWP, II.20.10.5; BW 12, p. 233. 
made in that connection to forgive because we have been forgiven by God in $\mathrm{Christ}^{84}$, are in agreement with the thinking of Grotius's opponent. Finally, De Bye comments on Grotius's observation that the use of violence is compatible with the biblical commandment to live an honest and virtuous life. In De Bye's view this cannot be reconciled with his 'cousin's' statement that to refrain from war reflects more holiness than waging a just war.

In conformity with their theological tenets, the Anabaptists did not try to influence the politics of the Dutch Republic with their pacifism. They only requested to be exempted from bearing arms. This, together with their refusal to take oaths or to participate in public offices, caused problems of different degrees in the several provinces. Gradually the Anabaptists obtained, also thanks to the interference of the stadholders William of Orange and Maurits, exemption of these duties, which were incompatible with their consciences. The Anabaptist had in general no objections to paying additional taxes instead. In the same line they sometimes had no problems to participate in the building of infrastructure for the defense. Some of them interpreted their pacifistic principle in a very narrow sense. An example is the Mennonite Jan Adriaensz. Leeghwater, who as an expert on drainage was prepared to inundate the land surrounding s'Hertogenbosch during the siege of this city by stadholder Frederik Hendrik in $1629 .{ }^{85}$

\section{Comparison}

We now come to a comparison between the different Christian thinkers on war and peace: Grotius, Erasmus and the Anabaptists.

To begin with it is clear that all share an important common frame of reference: the Bible. Its authority as divine revelation is accepted by all. They also have in common that they like to refer to the 'golden age' of early Christianity. Grotius and Erasmus build on the tradition of the Church as it appears in the writings of the Church fathers and the councils, in other words the 'official' church history. The Anabaptists keep the official tradition more at a distance. Their ideal is the New Testament model, while an important part of the postbiblical tradition, especially the unhappy intertwinement between church, power and violence after Constantine is rejected. Their history fits in the line

${ }^{84}$ LWP, II. 24.3.1; $B W 12$, p. 235; Grotius refers to Ephesians 4: 32.

${ }^{85}$ J.Th. de Visser, Kerk en Staat [Church and State] vol 2 (Leiden: Sijthoff, 1926), pp. 433440; S.L. Verheus, 'Beleden vrede - omstreden vrede. Het dopers vredesgetuigenis', in: Wederdopers, menisten, doopsgezinden, ed. by Groenveld, pp. 162-179. 
of the Christian currents that developed outside the institutional framework of the Church. They can be characterized as a kind of (forced) 'underground' movements, which came to the surface in the days of the Reformation. ${ }^{86}$

This is the background of a crucial difference as the theological framework of interpretation of biblical and church historical sources between, on the one hand Grotius and Erasmus, and on the other the Anabaptists. Grotius and Erasmus share the ideal of a whole Europe encompassing Christendom. Erasmus aims at the prevention of a realization of the schism within Christendom, while Grotius, who lived a generation later and faced the factual disruption of unity, tries to unite the Christian church again. This becomes even his major objective in the last part of his life. Both Erasmus and Grotius assume the great majority of the peoples of Europe to be Christians and more specifically that those who are part of the government could be addressed as such. Solemn titles as the 'Most Christian King of France and Navarre' are taken seriously by them. Those in government and their subjects are by means of their infant baptism part of the corpus christianum. Church membership and citizenship almost coincide. That explains the indignation of both authors when confronted with the fact that Christian governments and subjects are estranged from the Christian message of peace. All this, notwithstanding the fact that both Erasmus and Grotius where in theological terms in a sense more or less outsiders, having regard to their supra-confessional points of view of the Christian doctrine. The mindset of the Anabaptists is completely different. They look upon the Christian community as an island in a non-Christian society. Only those who have professed their personal faith belong to that community, which is visualized in the believer's baptism. Instead of the coalescence of church and society there is the chosen isolation from society and its institutions, in the first place the government. The quest for ruling the world has been replaced by the urge to separate from the world.

This brings us to the attitude vis-à-vis politics. Grotius is a full fledged participant, not only in political debate, but also in political practice. He is a man of the public office, as is exemplified by the various positions he fulfilled first in the service of the Dutch Republic and later on behalf of the Swedish Kingdom in Paris. The influence of his experiences in practice explains the sensitivity to the restrictions reality imposes on the idealism which is displayed in his writings. Erasmus is more in the margin of political life. His function as counsellor to the (future) emperor Charles V did not give him a lot of political

${ }^{86}$ E.H. Broadbent, The Pilgrim Church (Southampton: Pickering and Inglis, 1989; $1^{\text {st }}$ ed. 1931). 
power. He nevertheless is interested in politics and tries to influence both worldly and ecclesiastical authorities. The Anabaptists on the other hand are apolitical. Participation in government is excluded for a Christian. Their ideal in this world is to be realized within the Christian community. Their concern is to be exempted from public duties that interfere with their beliefs. Apart from that they consider themselves obliged to submit to the powers that are ordained by God.

\section{Final remarks}

Finally a word on the position of Grotius, Erasmus and the Anabaptists against the background of the ideas within Christianity on war and peace in general. It is submitted that Erasmus and the Anabaptists with their virtual or complete rejection of participation in warfare are congenial with many in the early Church. De Blois and Kramer write that until the third century most Christians were pacifists. The separation from the world and the literal interpretation of the Sermon on the Mount were crucial for their position. ${ }^{87}$ Church fathers like Origen, Tertullian and Lactantius seemed to share the same views. The pacifist ideas however disappear gradually from the official stands of the institutions of the Church, without however vanishing completely. Since the Reformation they are heard again more frequently. Grotius - notwithstanding his preference for the Early Church ${ }^{88}$ - is following newer developments in Church history as from Constantine. Church fathers like Ambrose and Augustine find theological justifications for warfare. Popes, Councils and the Reformers Luther and Calvin express similar views. Both approaches remain visible in the history of Christianity until the present day. ${ }^{89}$

\footnotetext{
${ }^{87}$ L. de Blois and G.H. Kramer, Kerk en vrede in de oudheid [Church and Peace in Antiquity] (Kampen: Kok Agora, 1986), pp. 35-72.

${ }^{88}$ A.H. Haentjes, Hugo de Groot als godsdienstig denker [Hugo Grotius as a religious thinker] (Amsterdam: Ploegsma, 1946), p. 104.

${ }^{89}$ Compare for example: H. McCoubrey, 'A Christian Approach to International Laws of Armed Conflict', in: Paul R. Beaumont (ed.), Christian Perspectives on Human Rights and Legal Philosophy (Carlisle: Paternoster, 1998), pp. 111-138; William D. Barrick, 'The Christian and War', The Master's Seminary Journal 11 (2000), p. 213-228.; Theo Boer, 'De rechtvaardige oorlog. Zoeken naar de zin van een eeuwenoud concept.' Nederlands Theologisch Tijdschrift, 67 (2003), pp. 89-107.
} 